\title{
Screening of chronic kidney disease (CKD) in general population on world kidney day on three consecutive years: A single day data
}

$\pi$
0
0
0
5
0
$\frac{\pi}{4}$

\section{Pradeep Kumar Rai ${ }^{1}$, Pawan Kumar Jindal ${ }^{2}$,} Punam Rai ${ }^{3}$,

Pramod Kumar Rai ${ }^{4}$, Sachindra Nat Rai ${ }^{5}$

${ }^{1}$ Consultant Nephrologist, Department of Nephrology, ${ }^{2}$ Consultant Urologist, Department of Urology, ${ }^{3}$ Consultant

Gynaecologist, Department of

Obstetrics and Gynaecology, ${ }^{4}$ Consustant Surgeon, Department of Surgery, ${ }^{5}$ Consustant Pediatric Surgeon, Department of Pediatric Surgery, OPAL Hospital, Kakarmatta, Varanasi, Uttar Pradesh, India

Address for the Correspondence: Dr. Pradeep Kumar Rai, Nephro-Urology Research Center,

OPAL Hospital, Kakarmatta, Varanasi, Uttar Pradesh, India. E-mail: pradnephro@gmail.com

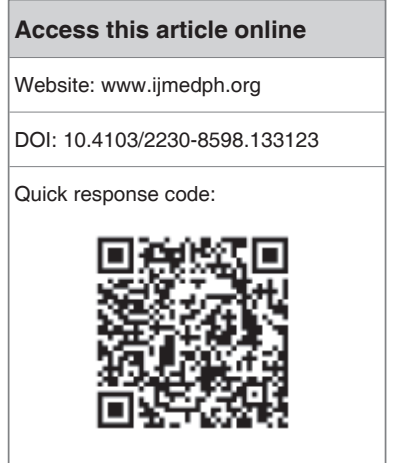

Objective: Chronic kidney disease (CKD) is increasingly recognized as a global public health problem. There is now convincing evidence that CKD can be detected using simple laboratory tests, and that treatment can prevent or delay complications of decreased kidney function, slow the progression of kidney disease and reduce the risk of cardiovascular disease (CVD). Currently, screening for CKD is accepted practice only in patients with hypertension or diabetes, but more widespread screening is increasingly proposed. We screened a sample of population on World Kidney Day on three consecutive years for detecting patients with CKD and to describe the natural course of the disease. Materials and Methods: Everyone aged $\geq 18$ was invited to participate. The study population was general population from Varanasi were screened in OPAL hospital. The survey comprised an extensive questionnaire and a brief clinical examination, including analysis of serum creatinine concentration in all participants. We screened all the participants who had at least one risk factor for CKD (including hypertension, diabetes mellitus, or a family history of CKD). Urine dipstick tests were done and blood sample was obtained to detect proteinuria and measure serum creatinine concentration, respectively. Results: A total of 547 participants were enrolled of which all 547 subjects were included in the analyses. The mean serum creatinine was $0.9525 \mathrm{mg} / \mathrm{dL}(0.900$ to 1.0050$)$. A high serum creatinine level was demonstrated in 16 participants (2.92\%), and 191 (34.91\%) were demonstrated to have proteinuria. There was a significant correlation between CKD and age, DM, urine protein and serum creatinine. There was no significant correlation between serum creatinine level and urinary protein excretion $(P=.001)$. There were no significant differences between CKD and gender. Conclusion: The study demonstrates that increasing age, diabetes mellitus, Serum creatinine and urinary protein were found significantly related to kidney disease with $P$ value of $0.02,0.0006,<0.0001,0.0002$, respectively, which means that there is a chance for the aged, diabetes patients and patients with elevated serum creatinine and urine protein to suffer with kidney disease with respect to the younger subject.

Key words: Age, chronic kidney disease, diabetes

\section{INTRODUCTION}

End-stage renal disease (ESRD) and its precursor chronic kidney disease (CKD) are emerging public health problems because of their associated adverse clinical outcomes, poor quality of life and high healthcare costs. Given that CKD (defined as glomerular filtration rate below $60 \mathrm{~mL} / \mathrm{min} / 1.73 \mathrm{~m}^{2}$ ) is often not detected until it is advanced, screening programs using blood or urine tests have been recommended. ${ }^{[1-3]}$ One strategy to address CKD is to identify the disease early through screening programs. One could screen the whole population to detect as many cases as possible. Currently, screening for CKD is accepted practice only in patients with hypertension or diabetes, but more widespread screening is increasingly proposed. Screening programs may also promote public awareness and education, encourage physician adherence to clinical practice guidelines and serve as medical outreach to underserved populations.

We conducted a camp-based screening of sample of general population on World Kidney Day on three consecutive years 2008, 2009 and 2010 for detecting patients with CKD. 


\section{MATERIALS AND METHODS}

In March 2008, 2009 and 2010 on World Kidney Day, camp was conducted in these mentioned three consecutive years in OPAL hospital, Varanasi (total of three camps). All Indians aged $\geq 18$ years of age were invited to participate in the study. All the participants provided informed consent.

We collected data on the information about personal characteristics, including age, sex, height, and weight, smoking, drug history, history for DM, hypertension, kidney disease, familial history for kidney disease, laboratory findings (urinalysis and serum creatinine). Systolic and diastolic blood pressures were measured only in one occasion. A urine dipstick (Medi-Test Combi 9-Macherey Nagel, Duren, Germany) was performed for each patient. Two milliliters of blood sample were collected from each patient through venipuncture to investigate for serum creatinine level. A high serum creatinine level was considered $1.5 \mathrm{mg} / \mathrm{dL}$ or higher in men and $1.3 \mathrm{mg} / \mathrm{dL}$ or higher in women. All individuals with a positive test result for kidney dysfunction or damage in the screening were referred to nephrologists, but they were not followed up.

Data were analyzed using the SPSS software (Statistical Package for the Social Sciences, version 16.0, SPSS Inc,Chicago, IL, USA). The independent $t$ test was used to compare quantitative variables, and the chi square test to compare proportions between groups. $P$ values lower than 0.05 was considered significant. Continuous variables were presented as mean \pm standard deviation.

\section{RESULTS}

A total of 547 participants were enrolled of which all 547 subjects were included in the analyses. They were 207 (37.84\%) women and 340 $(62.15 \%)$ men. The mean age of the participants was $41.02 \pm 14.03$ years. The mean body mass index (BMI) was $24.92 \pm 7.08 \mathrm{~kg} / \mathrm{m}^{2}$. The mean systolic blood pressure was $126 \pm 20.44 \mathrm{~mm} \mathrm{Hg}$ (95\% CI, 130.66 to 133.33$)$ and the mean diastolic blood pressure was $76.4 \pm$ $12.23 \mathrm{~mm} \mathrm{Hg}$ (95\% CI, 76.90 to 77.88) [Table 1]. Of 547 participants, $55(10.5 \%)$ were diabetic, $50(9.14 \%)$ were hypertensive and 13 $(2.7 \%)$ only had a positive family history for CKD. Concurrent DM and hypertension were present in 21 participants (3.8\%). 3 (0.54\%) were diabetic patients who had a positive familial history of CKD, 2 $(0.36 \%)$ were hypertensive patients who had a positive familial history of $\mathrm{CKD}$, and $1(0.18 \%)$ were diabetic and hypertensive patients with a positive familial history of CKD [Table 2].

The mean serum creatinine was $0.9525 \mathrm{mg} / \mathrm{dL}$ (0.900 to 1.0050). A high serum creatinine level was demonstrated in 16 participants $(2.92 \%)$, and 191 (34.91\%) were demonstrated to have proteinuria.

There was a significant correlation between CKD with age, DM, urine protein and S. creatinine. There was no significant correlation between serum creatinine level and urinary protein excretion $(P=0.001)$. Smoking did not have a relation with proteinuria or high serum creatinine level. There was no relationship between BMI and

Table 1: Mean values of screening data
\begin{tabular}{|l|r|r|r|r|r|r|}
\hline Variable & $\mathbf{N}$ & Mean & Std Dev & Sum & Minimum & Maximum \\
\hline Age & 547 & 41.02011 & 14.03207 & 22438 & 10.00000 & 86.00000 \\
\hline GENDER & 547 & 1.62157 & 0.48544 & 887.00000 & 1.00000 & 2.00000 \\
\hline DM & 525 & 0.10476 & 0.30654 & 55.00000 & 0 & 1.00000 \\
\hline S_Creat & 542 & 0.95994 & 0.60813 & 520.29000 & 0.50000 & 10.10000 \\
\hline CKD & 547 & 0.07130 & 0.25756 & 39.00000 & 0 & 1.00000 \\
\hline Alb & 538 & 0.78625 & 0.99198 & 423.00000 & 0 & 4.00000 \\
\hline BMI & 524 & 24.92500 & 7.08137 & 13061 & 7.60000 & 49.00000 \\
\hline Sugar & 539 & 0.05380 & 0.36947 & 29.00000 & 0 & 4.00000 \\
\hline
\end{tabular}

\begin{tabular}{|c|c|c|c|c|c|c|c|}
\hline \multirow[t]{2}{*}{ Factors } & \multirow[t]{2}{*}{ Kidney disease } & \multicolumn{2}{|c|}{ Gender $(N)$} & \multicolumn{2}{|c|}{ Gender (\%) } & \multicolumn{2}{|c|}{ Total (\%) } \\
\hline & & Female & Male & Female & Male & Female & Male \\
\hline \multirow{2}{*}{ Sex } & Not Present & 183 & 306 & 33.46 & 55.94 & \multirow{2}{*}{37.84} & \multirow{2}{*}{62.16} \\
\hline & Present & 24 & 34 & 4.39 & 6.22 & & \\
\hline \multirow{2}{*}{ DM } & Not Present & 17 & 25 & 30.91 & 45.45 & \multirow{2}{*}{38.18} & \multirow{2}{*}{61.82} \\
\hline & Present & 4 & 9 & 7.27 & 16.36 & & \\
\hline \multirow{2}{*}{ Obesity } & Not Present & 32 & 13 & 64.00 & 26.00 & \multirow{2}{*}{70.00} & \multirow{2}{*}{30.00} \\
\hline & Present & 3 & 2 & 6.00 & 4.00 & & \\
\hline \multirow{2}{*}{ HT } & Not Present & 19 & 16 & 38.00 & 32.00 & \multirow{2}{*}{50.00} & \multirow{2}{*}{50.00} \\
\hline & Present & 6 & 9 & 12.00 & 18.00 & & \\
\hline \multirow{2}{*}{ alb } & Not Present & 79 & 166 & 27.82 & 58.45 & \multirow{2}{*}{32.75} & \multirow{2}{*}{67.25} \\
\hline & Present & 14 & 25 & 4.93 & 8.80 & & \\
\hline \multirow{2}{*}{ Sugar } & Not Present & 6 & 8 & 37.50 & 50.00 & \multirow{2}{*}{43.75} & \multirow{2}{*}{56.25} \\
\hline & Present & 1 & 1 & 6.25 & 6.25 & & \\
\hline \multirow{2}{*}{ Smoking } & Not Present & 3 & 39 & 6.52 & 84.78 & \multirow{2}{*}{8.70} & \multirow{2}{*}{91.30} \\
\hline & Present & 1 & 3 & 2.17 & 6.52 & & \\
\hline \multirow{2}{*}{$\begin{array}{l}\text { h/o kidney } \\
\text { disease }\end{array}$} & Not Present & 5 & 13 & 20.00 & 52.00 & \multirow{2}{*}{32.00} & \multirow{2}{*}{68.00} \\
\hline & Present & 3 & 4 & 12.00 & 16.00 & & \\
\hline
\end{tabular}


serum creatinine level. However, there was significant correlation between BMI and diabetics subgroup $(P<0.001)$ [Table 3].

\section{DISCUSSION}

There is an epidemiological transition taking place in India, with the decline in communicable diseases and a growing burden of chronic disease. The World Health Organization laid down certain criteria for a major non-communicable disease (NCD), namely, (i) being a major cause of morbidity and mortality, (ii) being amenable to prevention by community-based strategies and (iii) sharing common risk factors with other NCDs. ${ }^{[4]}$ India has been described as the diabetes capital of the world, every fifth diabetic in the word being Indian. ${ }^{[5]}$ Hypertension is not far behind--the CURES cohort in Chennai showed that every fifth individual was hypertensive. ${ }^{[6]}$ The increasing prevalence of diabetes, hypertension and associated risk factors such as obesity, hypercholesterolemia and the metabolic syndrome underscores the potential for sustained and explosive growth of this epidemic. Recent publications have dealt with mainly single centre reports or regional population-based estimates.

Observational and anecdotal data suggest that the normal ranges of glomerular filtration rate (GFR) may be lower in the predominantly vegetarian, less muscular Indian subjects with different creatinine generation rates, compared to their western counterparts although this issue needs more rigorous study. ${ }^{[7,8]}$ Mani, ${ }^{\left[{ }^{9]}\right.}$ working in Chennai, South India, estimated a prevalence of chronic renal failure of 0.16 per cent in the community in 2003; applying the Modification in Diet in Renal Disease (MDRD) equation for GFR estimation in 2005, 0.86 per cent were found to have a GFR $<80 \mathrm{~mL} / \mathrm{min} / 1.73\left[\mathrm{~m}^{2}\right] \cdot{ }^{[10]}$ Agarwal and co-workers ${ }^{[11]}$ arrived at an estimate of 0.78 per cent for CKD, in a community-based sample in New Delhi defined by an elevated serum creatinine $>1.8 \mathrm{mg} / \mathrm{dL}$. Estimates for the United States (US) population extrapolated from the National Health and Nutrition Examination Survey (NHANES III) data place the prevalence of CKD stages 4 and 5 (severe decrease in GFR) and CKD stage 3 (moderate decrease in GFR) at 0.4 per cent. ${ }^{[12]}$ However, such direct comparisons with Western populations are not valid, since the equivalent GFR for a serum creatinine of $1.8 \mathrm{mg} / \mathrm{dL}$ in Indians may place the individual anywhere between CKD stages 2 to 4 depending upon gender and nutritional status.

Delayed recognition and treatment of CKD may predispose patients to adverse outcomes. ${ }^{[13]}$ Some of the more important negative outcomes include more rapid onset of end-stage renal disease, progression of co-morbid conditions such as anemia and cardiovascular disease

Table 3: Correlation of the selected screened data

\begin{tabular}{|c|c|c|c|c|c|c|c|c|}
\hline \multicolumn{9}{|c|}{$\begin{array}{c}\text { Pearson Correlation Coefficients } \\
\text { Prob }>|\mathbf{r}| \text { under } \mathrm{H} 0: \text { Rho }=0 \\
\text { Number of Observations }\end{array}$} \\
\hline & Age & GENDER & DM & S_Creat & CKD & Alb & BMI & Sugar \\
\hline Age & $\begin{array}{r}1.00000 \\
547\end{array}$ & $\begin{array}{r}-0.02416 \\
0.5729 \\
547\end{array}$ & $\begin{array}{r}0.28748 \\
<.0001 \\
525\end{array}$ & $\begin{array}{r}0.09682 \\
0.0242 \\
542\end{array}$ & $\begin{array}{r}0.09538 \\
0.0257 \\
547\end{array}$ & $\begin{array}{r}0.13018 \\
0.0025 \\
538\end{array}$ & $\begin{array}{r}0.08207 \\
0.0605 \\
524\end{array}$ & $\begin{array}{r}-0.03458 \\
0.4230 \\
539\end{array}$ \\
\hline GENDER & $\begin{array}{r}-0.02416 \\
0.5729 \\
547\end{array}$ & $\begin{array}{r}1.00000 \\
547\end{array}$ & $\begin{array}{r}0.00073 \\
0.9867 \\
525\end{array}$ & $\begin{array}{r}-0.01566 \\
0.7160 \\
542\end{array}$ & $\begin{array}{r}0.14295 \\
0.0008 \\
547\end{array}$ & $\begin{array}{r}0.08270 \\
0.0552 \\
538\end{array}$ & $\begin{array}{r}-0.06785 \\
0.1209 \\
524\end{array}$ & $\begin{array}{r}-0.03134 \\
0.4678 \\
539\end{array}$ \\
\hline DM & $\begin{array}{r}0.28748 \\
<.0001 \\
525\end{array}$ & $\begin{array}{r}0.00073 \\
0.9867 \\
525\end{array}$ & $\begin{array}{r}1.00000 \\
525\end{array}$ & $\begin{array}{r}0.06436 \\
0.1428 \\
520\end{array}$ & $\begin{array}{r}0.14881 \\
0.0006 \\
525\end{array}$ & $\begin{array}{r}0.23355 \\
<.0001 \\
516\end{array}$ & $\begin{array}{r}0.10077 \\
0.0240 \\
502\end{array}$ & $\begin{array}{r}0.25436 \\
<.0001 \\
517\end{array}$ \\
\hline S_Creat & $\begin{array}{r}0.09682 \\
0.0242 \\
542\end{array}$ & $\begin{array}{r}-0.01566 \\
0.7160 \\
542\end{array}$ & $\begin{array}{r}0.06436 \\
0.1428 \\
520\end{array}$ & $\begin{array}{r}1.00000 \\
542\end{array}$ & $\begin{array}{r}0.57067 \\
<.0001 \\
542\end{array}$ & $\begin{array}{r}0.03328 \\
0.4432 \\
533\end{array}$ & $\begin{array}{r}0.04837 \\
0.2713 \\
519\end{array}$ & $\begin{array}{r}-0.02418 \\
0.5771 \\
534\end{array}$ \\
\hline CKD & $\begin{array}{r}0.09538 \\
0.0257 \\
547\end{array}$ & $\begin{array}{r}0.14295 \\
0.0008 \\
547\end{array}$ & $\begin{array}{r}0.14881 \\
0.0006 \\
525\end{array}$ & $\begin{array}{r}0.57067 \\
<.0001 \\
542\end{array}$ & $\begin{array}{r}1.00000 \\
547\end{array}$ & $\begin{array}{r}0.16194 \\
0.0002 \\
538\end{array}$ & $\begin{array}{r}0.07526 \\
0.0852 \\
524\end{array}$ & $\begin{array}{r}-0.02051 \\
0.6347 \\
539\end{array}$ \\
\hline Alb & $\begin{array}{r}0.13018 \\
0.0025 \\
538\end{array}$ & $\begin{array}{r}0.08270 \\
0.0552 \\
538\end{array}$ & $\begin{array}{r}0.23355 \\
<.0001 \\
516\end{array}$ & $\begin{array}{r}0.03328 \\
0.4432 \\
533\end{array}$ & $\begin{array}{r}0.16194 \\
0.0002 \\
538\end{array}$ & $\begin{array}{r}1.00000 \\
538\end{array}$ & $\begin{array}{r}-0.04074 \\
0.3561 \\
515\end{array}$ & $\begin{array}{r}0.05100 \\
0.2376 \\
538\end{array}$ \\
\hline BMI & $\begin{array}{r}0.08207 \\
0.0605 \\
524\end{array}$ & $\begin{array}{r}-0.06785 \\
0.1209 \\
524\end{array}$ & $\begin{array}{r}0.10077 \\
0.0240 \\
502\end{array}$ & $\begin{array}{r}0.04837 \\
0.2713 \\
519\end{array}$ & $\begin{array}{r}0.07526 \\
0.0852 \\
524\end{array}$ & $\begin{array}{r}-0.04074 \\
0.3561 \\
515\end{array}$ & $\begin{array}{r}1.00000 \\
524\end{array}$ & $\begin{array}{r}0.01329 \\
0.7633 \\
516\end{array}$ \\
\hline Sugar & $\begin{array}{r}-0.03458 \\
0.4230 \\
539\end{array}$ & $\begin{array}{r}-0.03134 \\
0.4678 \\
539\end{array}$ & $\begin{array}{r}0.25436 \\
<.0001 \\
517\end{array}$ & $\begin{array}{r}-0.02418 \\
0.5771 \\
534\end{array}$ & $\begin{array}{r}-0.02051 \\
0.6347 \\
539\end{array}$ & $\begin{array}{r}0.05100 \\
0.2376 \\
538\end{array}$ & $\begin{array}{r}0.01329 \\
0.7633 \\
516\end{array}$ & $\begin{array}{r}1.00000 \\
539\end{array}$ \\
\hline
\end{tabular}


(CVD), suboptimal vascular access at initiation of dialysis, increased use of centre-based hemodialysis, increased hospitalization, increased cost and worse survival. ${ }^{[14]}$ Early detection of disease via performing screening programs is widely recommended. ${ }^{[15]}$ In this study, we utilized urinary protein excretion and serum creatinine level for screening of the population at risk for CKD. The study by Iseki in the Okinawa region of Japan demonstrated that proteinuria and high serum creatinine level are two valuable prognostic factors for end-stage renal disease. ${ }^{[16]} \mathrm{A}$ high serum creatinine level was demonstrated in 16 participants (2.92\%), and a high proteinuria in 191 (34.91\%). We used serum creatinine and urine protein as the base to diagnose CKD; however, it would be better to utilize GFR formulas to measure GFR. However, because an overtly high serum creatinine level and urine protein (if measured) is more likely to draw the physician's attention compared to a diminished GFR with a "normal appearing" creatinine level, especially in the elderly, the serum creatinine was preferred. ${ }^{[17]}$ Several studies have been performed to screen for CKD among the Indian population. The prevalence of a serum creatinine level in our study $(34.91 \%)$ is lower than that in other studies. In our study, increasing age, diabetes mellitus, serum creatinine and urinary protein were found significantly related to kidney disease with $P$ value of $0.02,0.0006,<0.0001,0.0002$, respectively, which means that there is a chance for the aged, diabetes patients and patients with elevated serum creatinine and urine protein to suffer with kidney disease with respect to the younger subject.

The most important disparity between our study and these studies was the population characteristics, which, in our study, is limited to the general population. Moreover we enrolled healthy and young subjects.

The followings are the limitations of current study, but also are the most important results of it: (1) this study did not include any followup of the subjects, and so no data is available regarding the outcome of disease. (2) Data regarding the treatment regimens for the therapy of DM or hypertension in diabetic and hypertensive patients were not completely available. The screening team members are trained very well about the importance of filling all inquired data. (3) In this study we used volunteer researchers for our screening team, but this experience determined that a screening project needs more formal and institutional involvement of healthcare system. The other limitation in our study was regarding our applied criteria for the diagnosis of CKD (high serum creatinine level and proteinuria in dipstick study). It could be better to use other standard methods of determining CKD, such as calculating GFR. However, the feasibility of using GFR formulas for determining CKD remains a concern. Finally, our results may not be applicable in other regions of India or other countries. More educational programs about the increasing risk of CKD in the population, especially among high-risk groups, should be planned.

\section{CONCLUSION}

There is a chance for the aged, diabetes patients and patients with elevated serum creatinine and urine protein to suffer with kidney disease with respect to the younger subject.

\section{ACKNOWLEDGMENT}

We gratefully acknowledge the voluntary and active participation of all study subjects. We are very much thankful to all the Resident medical officers Dr Santosh Mishra, Dr Shashikumar Gupta, Dr Hemant Rai, Dr Raza and Dr Surendra Gupta for their extensive support to conduct the study. We are thankful to Ms.Aarushi Rai who helped us in data management. Authors acknowledge the great help received from the scholars whose articles cited and included in references of this manuscript. Authors are grateful to IJCRR editorial board members and IJCRR team of reviewers who have helped to bring quality to this manuscript.

\section{REFERENCES}

1. National Kidney Foundation. K/DOQI clinical practice guidelines for chronic kidney disease: Evaluation, classification, and stratification. Am J Kidney Dis 2002;39(suppl 1):1-266s.

2. Powe NR, Boulware LE. Population-based screening for CKD. Am J Kidney Dis 2009;53(suppl 3):64-70s.

3. Powe NR, Plantinga L, Saran R. Public health surveillance of CKD: Principles, steps, and challenges. Am J Kidney Dis 2009;53(suppl 3):37-45s.

4. WHO Regional Office for South East Asia; New Delhi: Non-communicable Diseases in South-East Asia Region - A profile; 2002.

5. Joshi SR, Parikh RM. India - Diabetes capital of the world: Now heading towards hypertension. J Assoc Physicians India 2007;55:323-4.

6. Mohan V, Deepa M, Farooq S, Datta M, Deepa R. Prevalence, awareness and control of hypertension in Chennai - the Chennai Urban Rural Epidemiology Study (CURES-52). J AssocPhysicians India 2007;55:326-32.

7. Best clinical practice guidelines for chronic kidney disease in India. Indian J Nephrol 2005;15(Suppl1):S1-6.

8. Mahajan S, Mukhiya GK, Singh R, Tiwari SC, Kalra V, Bhowmik DM, et al. Assessing glomerular filtration rate in healthy Indian adults: A comparison of various prediction equations. J Nephrol 2005;18:257-61.

9. Mani MK. Prevention of chronic renal failure at the community level. Kidney IntSuppl2003;83(Suppl):S86-9.

10. Mani MK. Experience with a program for prevention of chronic renal failure in India. Kidney IntSuppl2003;94 (Suppl):S75-8.

11. Agarwal SK, Dash SC, Irshad M, Raju S, Singh R, Pandey RM. Prevalence of chronic renal failure in adults in Delhi, India. Nephrol Dial Transplant 2005;20:1638-42.

12. K/DOQI Clinical practice guidelines for chronic kidney disease: Evaluation, classification and stratification. Am J Kidney Dis 2002;39:S1-266.

13. Cohen JT, Jasimuddin SK, Tommasulo BC, Shapiro EY, Singavarapu A, Vernatter $\mathrm{J}$, et al. Underdiagnosis of chronic kidney disease in the nursing home population. J Am GeriatrSoc2009;57:1123-4.

14. Mendelssohn DC. Coping with the CKD epidemic: The promise of multidisciplinary team-based care. Nephrol Dial Transplant2005;20:10-2.

15. Aghighi M, Mahdavi-Mazdeh M, Zamyadi M, HeidaryRouchi A, Rajolani $\mathrm{H}$, Nourozi S. Changing epidemiology of end-stage renal disease in last 10 years in Iran. Iran J Kidney Dis2009;3:192-6.

16. Iseki K. The Okinawa screening program. J Am SocNephrol 2003;14:S127-30.

17. Grootendorst DC, Jager KJ, Zoccali C, Dekker FW.Screening: Why, when, and how. Kidney Int2009;76:694-9.

How to cite this article: Rai PK, Jindal PK, Rai P, Rai PK, Rai SN. Screening of chronic kidney disease (CKD) in general population on world kidney day on three consecutive years: A single day data. Int J Med Public Health 2014;4:167-70.

Source of Support: Nil, Conflict of Interest: The authors declare that they have no conflicting interests. 